\title{
Molecular composition of the outermost capsular material of the tubercle bacillus
}

\author{
Annick Ortalo-Magné, ${ }^{1}$ Marie-Ange Dupont, ${ }^{2}$ Anne Lemassu, ${ }^{1}$ \\ Ase B. Andersen, ${ }^{3}$ Pierre Gounon ${ }^{4}$ and Mamadou Daffé ${ }^{1}$
}

\footnotetext{
1 Département des Glycoconjugués et Biomembranes, Laboratoire de Pharmacologie et Toxicologie Fondamentales du CNRS (UPR 8221), 118 route de Narbonne, 31062 Toulouse Cedex, France

2 Laboratoire de Biologie Moléculaire Eucaryote du CNRS (UPR 9006), 118 route de Narbonne, 31062 Toulouse Cedex, France

3 Mycobacterial Department, Division of Biotechnology, Statens Seruminstitut, 5 Artillerivej, DK-2300 Copenhagen S, Denmark

4 Institut Pasteur, Station centrale de microscopie électronique, 25 rue du Docteur Roux, 75724 Paris Cedex 15, France
}

\author{
Author for correspondence: M. Daffé. Tel: +33613359 16. Fax: +33613358 86 . \\ e-mail: daffe@lptf. biotoul. fr
}

Keywords: tuberculosis, mycobacteria, polysaccharides, capsule

\section{INTRODUCTION}

Mycobacterium tuberculosis, the causative agent of tuberculosis, is responsible for more deaths annually than any other single bacterial pathogen (Bloom \& Murray, 1992;

Abbreviations: AG, arabinogalactan; ConA, concanavalin A; FAB-MS, fast atom bombardment mass spectrometry; LAM, lipoarabinomannan; LM, lipomannan; mAbs, monoclonal antibodies; PIMs, phosphatidylinositol mannosides.
Kochi, 1991). To establish infection, this facultative intracellular bacillus must first survive its encounter with alveolar macrophages and then gain access to the lymphatics or the bloodstream (Patel \& Abraham, 1989). With many bacterial pathogens, their capacity to produce toxins or extracellular enzymes can be correlated with their capacity to produce disease. It is unclear which of these mechanisms, if any, pathogenic mycobacteria use to survive within the host. Part of the pathogenesis of the mycobacterial infections is currently attributed to the 
extraordinarily high lipid contents of the cell walls of members of the genus Mycobacterium, constituting up to $60 \%$ of their dry weight (Goren \& Brennan, 1979). Indeed, the fact that mycobacteria are appreciably more resistant to deleterious agents, such as acids, alkalis, and germicides, supports this concept. However, to produce disease, other factors are obviously required, as nonpathogenic mycobacterial species also elaborate complex and unusual compounds, structurally related to those found in the pathogenic ones. Among these factors, the capsule which surrounds only pathogenic mycobacteria (Hanks, 1961 ; Draper \& Rees, 1970) is postulated to be a defence barrier against the phagocytic cells. Furthermore, this capsule also determines what components come into contact with the cells and tissues of the host or are recognized by the immune system. The nature of this capsule has been chemically defined in two species, namely M. lepraemurium (Draper \& Rees, 1973) and M. leprae (Boddingius \& Dijkman, 1989; Hunter \& Brennan, 1983), where it has been shown to contain species-specific glycolipids surrounding the pathogens inside their host cells. In the case of $M$. tuberculosis, although speciesspecific glycolipids have been characterized in some strains (Daffé et al., 1987, 1991a, b), the nature of its capsule remains unknown, as these lipids were not detected in some of the virulent tubercle bacilli (Daffé $e t$ al., 1987, 1991a, b). To address this fundamental issue, the outermost capsular material of M. tuberculosis was isolated and its major constituents were characterized.

\section{METHODS}

Strain and growth conditions. Mycobacterium tuberculosis $\mathrm{H}_{37} \mathrm{Rv}$ (ATCC 27294, CIPT 14-00100-001) was grown on synthetic Sauton's medium (Sauton, 1912) (100 ml per flask) either as surface pellicles in static cultures or on an orbital shaker at $37^{\circ} \mathrm{C}$.

Production of day-7 culture filtrate. Seven-day short-term culture filtrate of $M$. tuberculosis was produced essentially as described by P. Andersen et al. (1991). After day 7, the bacterial cells were removed from the growth medium by filtration (Milliguard Housing system, Millipore) and the culture filtrate was concentrated $(\times 100)$ on an Amicon YM3 membrane resulting in protein concentrations ranging from 5 to $10 \mathrm{mg} \mathrm{ml}^{-1}$.

Isolation and fractionation of the crude outermost capsular material. Cells were harvested by pouring off the medium and gently shaken for $1 \mathrm{~min}$ with $10 \mathrm{~g}$ glass beads ( $4 \mathrm{~mm}$ diameter) per $2 \mathrm{~g}$ wet cells (Buttiaux et al., 1966; Kreis, 1966). The resulting material was then suspended in distilled water or light petroleum (boiling point range $\left.35-50^{\circ} \mathrm{C}\right) /$ diethyl ether $(1: 1$, $\mathrm{v} / \mathrm{v})(50 \mathrm{ml}$ per flask) and immediately filtered through a $0.2 \mu \mathrm{m}$ sterile filter (Nalgene). In order to check that no lipid was adsorbed on the filter, in a control experiment the bacterial suspension was filtered through a no. 111 Durieux filter paper.

The material removed by the beads in water was concentrated under vacuum to $1 / 10$ of the original volume. A portion $(1 / 10)$ of this crude filtrate was extensively dialysed against distilled water and analysed for carbohydrate and protein content by colorimetric assays (Dische, 1962; Lowry method). Chloroform and methanol were added to the remaining portion to obtain a partition mixture composed of chloroform $/ \mathrm{methanol} /$ water
( $3: 4: 3$, by vol.). After acid hydrolysis of the different partition layers, arabinose (Ara), mannose (Man) and traces of xylose (Xyl) were identified in the aqueous layer; glucose (Glc) was the only sugar constituent detected in the hydrolysis products of the interphase. The organic layer contained Man and Glc.

The material extracted by light petroleum/diethyl ether was partitioned between chloroform and water $(1: 1, v / v)$. Acid hydrolysis of the aqueous layer led to the identification of Glc as the main sugar constituent whereas Man and Glc were detected in hydrolysis products of the chloroform extract.

Extraction of the interphase derived from the partition experiment (conducted on the material recovered by beads in water) several times with water resulted in the recovery of an opalescent solution which contained Glc as the only sugar constituent. The Ara/Man- and Glc-rich fractions were concentrated and the polymers were precipitated overnight at $4{ }^{\circ} \mathrm{C}$ with 6 vols cold ethanol. The precipitates were collected after centrifugation at $14000 \mathrm{~g}$ for $1 \mathrm{~h}$, dissolved in distilled water, the polymers precipitated again with ethanol, re-centrifuged and the precipitates dialysed for $3 \mathrm{~d}$ against water to eliminate traces of salts, then lyophilized and weighed.

Subcellular fractionation of $\boldsymbol{M}$. tuberculosis. Cells were harvested by centrifugation ( $8000 \mathrm{~g}$ for $30 \mathrm{~min}$ ) and washed twice in cold PBS $(0.145 \mathrm{M} \mathrm{NaCl} ; 0.15 \mathrm{M}$ sodium phosphate). The wet pellet was weighed and resuspended at a ratio of $1 \mathrm{ml}$ ( $\mathrm{g}$ bacteria) $^{-1}$ (in this case $23 \mathrm{~g}$ wet pellet) in a lysis buffer consisting of PBS supplemented with the protease inhibitor PMSF (Boehringer Mannheim) and EDTA to a final concentration of $1 \mathrm{mM}$. The bacteria were lysed using a French pressure cell (Aminco, American Instrument) contained in a MSC III safety cabinet at a pressure of 12000 p.s.i. (82.8 MPa). This procedure was repeated three times. Bacterial cells resisting this treatment were recovered by low speed centrifugation $(1000 \mathrm{~g}$ for $30 \mathrm{~min})$. The supernatant was recentrifuged for $20 \mathrm{~min}$ at $20000 \mathrm{~g}$. The pellet from this centrifugation was assumed to consist mainly of cell walls. The supernatant represented a mixture of cytoplasmic components and cell membranes. RNA was degraded by RNase treatment for $1 \mathrm{~h}$ at $4{ }^{\circ} \mathrm{C}$ after which the sample was subjected to ultracentrifugation at $100000 \mathrm{~g}$ for $3 \mathrm{~h}$ at $5^{\circ} \mathrm{C}$ in a fixed angle rotor (TH1270, Sorvall, DuPont Medical Products). The pellets (containing the cell membranes) were washed in fresh lysis buffer and recentrifuged.

Purification and chemical characterization of the different polysaccharides. The different polysaccharides were purified as previously described in detail (Lemassu \& Daffé, 1994). Briefly, Ara/Man-containing polysaccharides and Glc-rich polysaccharide were chromatographed on a column of DEAE-Trisacryl gel and the neutral fractions were rechromatographed on columns of Bio-Gel P-10 and Sephadex G-200, respectively. The elution profiles of both types of gel-filtration chromatography were monitored by refractive index detection and the collected fractions were assessed for their carbohydrate content.

Purified polysaccharide samples were acetolysed (Stewart \& Ballou, 1968) and methylated according to the method of Ciucanu \& Kerek (1984). Portions of the per-O-methylated products were hydrolysed with $2 \mathrm{M} \mathrm{CF}_{3} \mathrm{COOH}$ at $110^{\circ} \mathrm{C}$ for $2 \mathrm{~h}$, reduced with $\mathrm{NaBH}_{4}$ and acetylated. The different partially $O$-methylated and partially acetylated alditols were identified by GC-MS

The dialysed culture filtrates and the various chromatographic fractions were assessed for the presence of proteins (Lowry method) and carbohydrates (Dische, 1962). The percentage of 
carbohydrates was also determined by GC using erythritol as internal standard.

The absolute configuration (D or L) of Ara, Man and Glc was determined by GC analysis of the trimethylsilyl derivatives of $(R)-(-)$ - and $(S)-(+)$-2-butyl glycosides as described (Gerwig et al., 1978). GC, GC-MS, fast atom bombardment (FAB)-MS and NMR were performed as described previously (Lemassu \& Daffé, 1994).

SDSPAGE. Samples $(20 \mu \mathrm{g})$ of dialysed materials were analysed by PAGE in a $10-20 \%(\mathrm{w} / \mathrm{v})$ gradient of SDS-polyacrylamide under reducing conditions. The gels were stained by a silver staining method (Bio-Rad). Molecular mass markers, obtained from Bio-Rad, were as follows: phosphorylase $b(97 \cdot 4 \mathrm{kDa})$, BSA $(66.2 \mathrm{kDa})$, ovalbumin $(45 \mathrm{kDa})$, carbonic anhydrase $(31 \mathrm{kDa})$, trypsin inhibitor $(21.5 \mathrm{kDa})$ and lysozyme $(14.4 \mathrm{kDa})$.

Western blot analysis. In Western blot (immunoblot) experiments, the proteins separated by PAGE were transferred onto nitrocellulose sheets (Schleicher \& Schuell BA85) in a semi-dry blotting apparatus according to the instructions provided by the manufacturer (Ancos) and reactive sites were blocked with $0.5 \%$ Tween $20(\mathrm{w} / \mathrm{v})$ in PBS, $\mathrm{pH} 7 \cdot 6$. The blots were incubated for $2 \mathrm{~h}$ at room temperature (or overnight at $4{ }^{\circ} \mathrm{C}$ ) with monoclonal antibodies (mAbs) directed against specific secreted proteins: HYT 6 and HYT 27 (Andersen et al., 1986), HBT 12 and HBT 10 (Ljungqvist et al., 1988) and L24b5 (A. B. Andersen et al., 1991); the mAbs were diluted in PBS ( $\mathrm{pH} \mathrm{7.6)} \mathrm{containing}$ $0.37 \mathrm{M} \mathrm{NaCl}$ and $0.05 \%(\mathrm{w} / \mathrm{v}$ ) Tween 20 (culture supernatants were diluted 1:25, and protein A culture supernatant mAbs were diluted $1: 500$ ). Bound $\mathrm{mAbs}$ were detected by using horseradish-peroxidase-coupled rabbit anti-mouse immunoglobulins (P216; Dakopatts) at a dilution of 1:1000. Colour reaction was obtained by using $3,3^{\prime}, 5,5^{\prime}$-tetramethylbenzidine.

ELISA. Sonicated cells of $M$. tuberculosis $(0.2 \mathrm{mg})$ and $5 \mu \mathrm{g}$ arabinogalactan (AG) (Daffé et al., 1990) and $10 \mu \mathrm{g}$ phosphatidylinositol mannosides (PIMs) (Fournié et al., 1991) were dissolved in $1 \mathrm{ml}$ ethanol; $2 \mu \mathrm{g}$ lipoarabinomannan (LAM) of M. tuberculosis $\mathrm{H}_{37} \mathrm{Rv}$ (Venisse et al., 1993) was dissolved in $1 \mathrm{ml}$ ethanol/water $(1: 1, \mathrm{v} / \mathrm{v})$. Samples $(50 \mu \mathrm{l})$ of these antigens were applied to the wells of a polystyrene microtitre plate (Nunc Immuno Plate I) and allowed to evaporate at $37^{\circ} \mathrm{C}$ overnight. The wells were blocked with $200 \mu 130 \%$ (w/v) powdered skimmed milk (PSM) with $0.1 \%$ Tween 20 in PBS at $37^{\circ} \mathrm{C}$ for $2 \mathrm{~h}$. The plate was rinsed five times with 1\% PSM in PBS and $100 \mu \mathrm{l}$ per well of $\mathrm{mAb}$ L9 (Gaylord et al., 1987) diluted $(1: 10, \mathrm{v} / \mathrm{v})$ in $0.4 \%$ PSM were deposited and left for $2 \mathrm{~h}$ at $37^{\circ} \mathrm{C}$. After five rinses, $100 \mu \mathrm{l}$ horseradish-peroxidase-linked anti-mouse antibody (Amersham), diluted according to the supplier's instructions, was added to the wells and left for $2 \mathrm{~h}$ at $37^{\circ} \mathrm{C}$. After five washings, $100 \mu \mathrm{l} p$-nitrophenyl phosphate substrate (Sigma) was added, followed by a $30 \mathrm{~min}$ incubation at $37^{\circ} \mathrm{C}$. The $A_{405}$ was read with a Multiscan apparatus (Flow Laboratories). Each value was measured in triplicate.

\section{Electron microscopy}

Transmission electron microscopy. Transmission electron microscopy was performed with a JEOL, JEM 1200 EX operating at $80 \mathrm{kV}$.

Cells harvested either by pouring off the culture medium or after treatment with glass beads were suspended in PBS and mounted on nickel grids. After six washings with PBS, cells were successively incubated with $0.26 \mathrm{M} \mathrm{NH}_{4} \mathrm{Cl}$ for $5 \mathrm{~min}, 5 \%$ (w/v) BSA in PBS for 10 min and then with $20 \mu$ liluted L9 $\mathrm{mAb}$ (Gaylord et al., 1987) (1:100 in 5\% BSA in PBS) for $5 \mathrm{~h}$ at room temperature. In control grids incubation with $\mathrm{mAb}$ was omitted. Cells were washed six times with $5 \%$ BSA in PBS and incubated with $20 \mu$ diluted (1:20 in 5\% BSA in PBS) gold-labelled $(10 \mathrm{~nm})$ goat anti-mouse immunoglobulins (Sigma) for $1 \mathrm{~h}$ at room temperature. The material was washed six times with PBS, fixed by an overnight incubation with $3 \%(\mathrm{v} / \mathrm{v})$ glutaraldehyde and washed three times with PBS.

Cells mounted on grids and washed as described above were incubated with diluted $(1: 5$ in cacodylate buffer, $\mathrm{pH} 7 \cdot 4)$ goldlabelled $(5 \mathrm{~nm})$ concanavalin A (ConA, Sigma) for $3 \mathrm{~h}$ at room temperature. Control cells were incubated with a ConA solution which had been preincubated in the presence of $550 \mathrm{nM} \alpha-\mathrm{D}$ methylmannoside in order to saturate the lectin-binding sites. After six washings with cacodylate buffer, the materials were fixed with $3 \%$ glutaraldehyde and then washed as above.

For thin sectioning, cells were washed twice with PBS and fixed overnight with $8 \%(\mathrm{w} / \mathrm{v})$ paraformaldehyde in PBS at $4{ }^{\circ} \mathrm{C}$. Fixed cells were washed three times by centrifugation $(500 \mathrm{~g}$ for $5 \mathrm{~min}$ ) in PBS. The pellet was resuspended in $100 \mu \mathrm{l} 15 \%(\mathrm{w} / \mathrm{v})$ BSA and $10 \mu \mathrm{l} 25 \%$ (w/v) glutaraldehyde was added to the suspension. After $20 \mathrm{~min}$ reaction at $20^{\circ} \mathrm{C}$, blocks were dispersed and conserved in $1.6 \mathrm{M}$ saccharose containing $25 \%$ polyvinylpyrrolidone. The resulting material was frozen in nitrogen at $-100{ }^{\circ} \mathrm{C}$ and thin-sectioned on a Reichert Ultracut ultramicrotome, while maintaining the specimen at $-80^{\circ} \mathrm{C}$.

Immunocytochemistry on thin sections was performed on membrane-coated nickel grids previously washed three times with distilled water, $0.26 \mathrm{M} \mathrm{NH}_{4} \mathrm{Cl}$ solution and $5 \% \mathrm{BSA}$ in PBS, respectively. The grids were incubated in $20 \mu$ diluted L9 $(1: 100$ in $5 \%$ BSA-PBS).

Cells were negatively stained using phosphotungstic acid.

Scanning electron microscopy. Cells were washed twice in $100 \mathrm{mM}$ HEPES buffer, $\mathrm{pH} 6.9$, and harvested by centrifugation $(8000 \mathrm{~g}$, $10 \mathrm{~min})$. The resulting pellet was resuspended in $1 \%(\mathrm{v} / \mathrm{v})$ glutaraldehyde in $100 \mathrm{mM}$ HEPES buffer for $1 \mathrm{~h}$ at $4{ }^{\circ} \mathrm{C}$. The cells were washed five times in the same buffer, and then small aliquots were deposited on glass coverslips previously made sticky with a short treatment with 3-aminopropyltriethoxysilane. Cells on coverslips were postfixed for $30 \mathrm{~min}$ at room temperature in $1 \%(\mathrm{w} / \mathrm{v})$ osmium tetroxide in HEPES, and then rinsed with distilled water. Cells were suspended in $1 \%$ $(\mathrm{w} / \mathrm{v})$ aqueous uranyl acetate for $1 \mathrm{~h}$ at room temperature and then washed five times in distilled water. Suspended cells were collected on $0.4 \mu \mathrm{m}$ Nuclepore membranes before dehydration through a graded ethanol series. Dehydrated cells were immersed for $10 \mathrm{~min}$ in hexamethyldisilazane and quickly air dried. Coverslips were sputter-coated with $5 \mathrm{~nm}$ gold/ palladium and specimens were examined with a JEOL JSM-35 CF scanning electron microscope operating under standard conditions.

\section{RESULTS}

\section{Effects of the mechanical treatment on the integrity of cells}

Gentle shaking of mycobacteria with $4 \mathrm{~mm}$-diameter glass beads is known to disperse mycobacterial clumps commonly occurring in cultures (Buttiaux et al., 1966; Kreis, 1966). However, the use of such a method for isolating the outermost constituents of the cells requires the control of both the extent of the cellular disruption and the effectiveness of extraction. Thus, untreated-control and glass-bead-treated cells were examined by scanning electron microscopy (Fig. 1). Control cells were aggregated in 

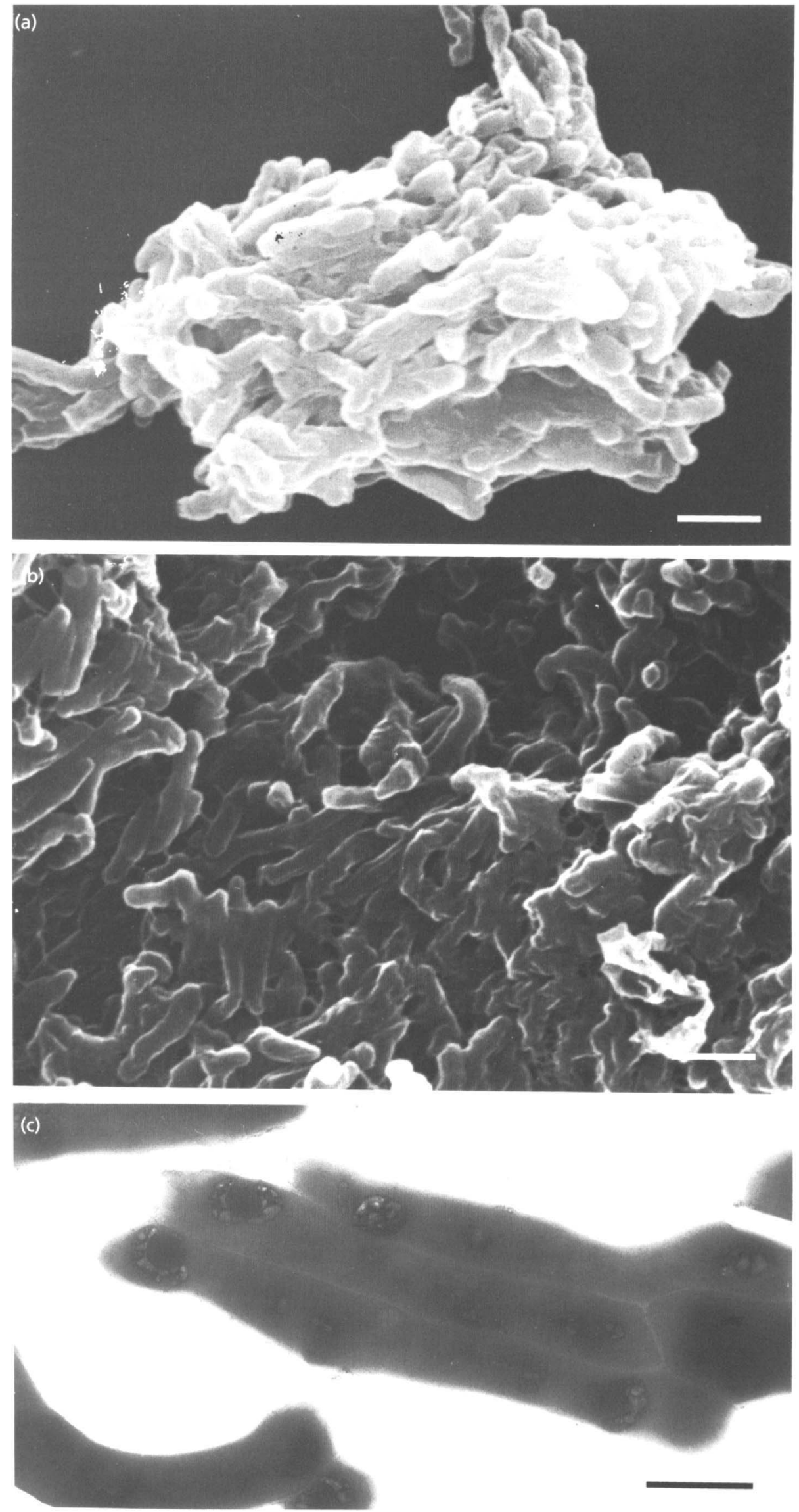
large clumps covered by an amorphous material which obliterated individual bacilli (Fig. 1a). Treatment of cells with glass beads resulted in the dispersion of these large clumps with a concomitant disappearance of the majority of the covering material (Fig. 1b). Bacterial suspension obtained by treatment of cells with glass beads was also negatively stained and examined by electron microscopy (Fig. 1c). Intact rod-shaped bacilli were seen with no paired fibrous structures usually visible on the walls (Draper, 1982). The cytochemical observations were confirmed by chemical data obtained on the hydrolysis products of the crude filtrate derived from the glass-beadtreated bacterial suspension. Neither galactose nor 6-Omethyl-glucose (which are known to be specific components of mycobacterial cell wall and cytosolic polysaccharides) was detected in the filtrate. It was thus concluded that the mechanical treatment used in the present study did not affect the integrity of the bacilli.

\section{Nature of the outermost cellular material}

The unfractionated material extracted from actively growing tubercle bacilli mechanically shaken with glass beads was recovered by water or by organic solvents. The water-recovered material represented $2-3 \%$ of the dried bacterial mass and was composed of 94-99\% proteins and carbohydrates. Small amounts of lipids (1-6\%) were also detected. The same composition was obtained using different types of filters, suggesting that no selection was made on the basis of the chemical nature of the compounds. Nevertheless, a slightly better recovery was observed using the Durieux filter than the Nalgene one $(+5-8 \%)$. The relative ratio of carbohydrates versus proteins varied from $3: 2$ to $3: 7$, depending on the growth phase of the strain. It was also important to check that the mechanical processing used was not a partitioning process between an aqueous medium and the hydrophobic mycoloyl-arabinogalactan of the mycobacterial wall leading to an underestimation of the amounts of noncovalently bound lipids in the aqueous medium. The organic solvent extract of the material removed by the beads in water represents only $1-2 \%$ of the water extract. Analysis of the lipid composition of the former material demonstrated that it contained the same compounds as those identified in processing with water, notably dimycocerosate of phthiocerol, in agreement with the results of Koul \& Gastambide-Odier (1977). The presence of this highly hydrophobic molecule in the water phase showed that the extraction method used in the present study was also suitable for detecting the presence of lipid compounds. Therefore, the recovery of the material by water was selected for subsequent experiments.

\section{SDSPAGE and Western blot analysis of proteins}

Macromolecules derived from the ethanol precipitation of the outermost cell constituents were analysed by SDSPAGE and compared to those isolated from the cytosol

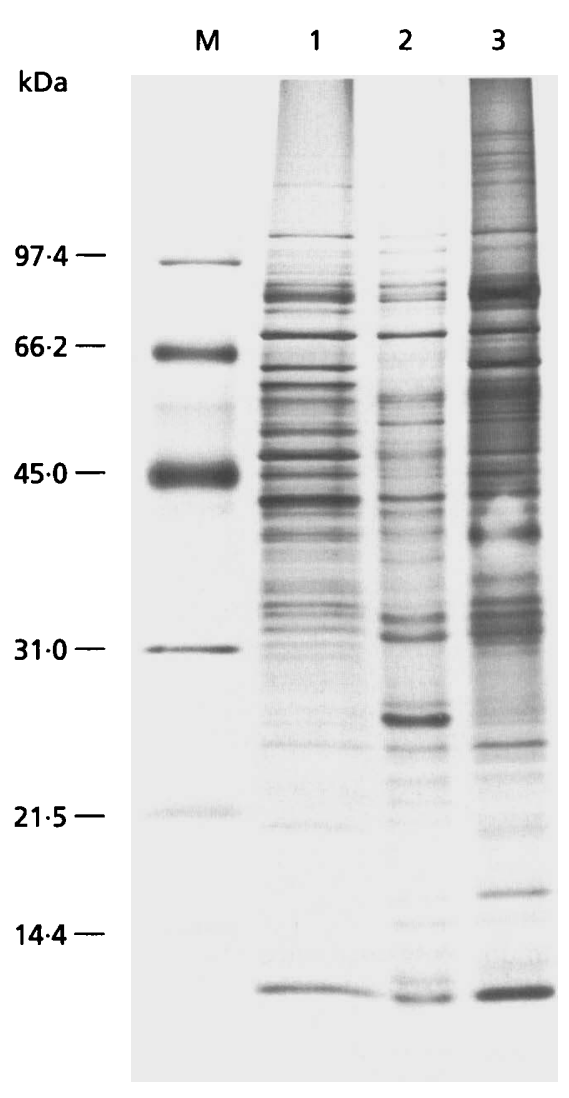

Fig. 2. Silver-stained SDS-PAGE of the cytosol (lane 1), $7 \mathrm{~d}$ culture filtrate (lane 2) and surface-exposed material (lane 3) of $M$. tuberculosis. Molecular mass markers (in $\mathrm{kDa}$ ) are indicated to the left of the figure (lane M).

and from the early $(7 \mathrm{~d})$ culture filtrate proteins. The silver-stained gels (Fig. 2) showed several protein bands common to the material derived from the culture filtrate and that obtained from the mechanical treatment of cells. However, some differences existed between the two materials. For instance, only minute amounts of the prominent $24 \mathrm{kDa}$ culture filtrate protein were detected in the surface-exposed material; likewise, only tiny amounts of two surface-exposed proteins ( 38 and $58 \mathrm{kDa}$ ) were found in the culture filtrate material.

To further characterize some of the surface-exposed proteins, Western blot analyses were performed on these latter proteins using mAbs directed against selected culture filtrate proteins (Fig. 3a-e). HYT 6 and HYT 12 mAbs, which recognize epitopes of the mycobacterial lipoproteins 19 and $38 \mathrm{kDa}$, respectively, reacted with protein bands exhibiting the corresponding molecular masses (Fig. 3a, b). Similarly, HYT 27, a mAb specifically reacting with the $30 / 31 \mathrm{kDa}$ fibronectin-binding proteins, gave strong reactions with pairs of the culture filtrate and surface-exposed proteins (Fig. 3c). L24b5 mAb strongly

Fig. 1. Scanning electron microscopy of control (a) and glass-bead-treated (b) cells and negatively stained bacilli (c). Bars, $1 \mu \mathrm{m}(\mathrm{a}, \mathrm{b})$ and $500 \mathrm{~nm}(\mathrm{c})$. 
(a)

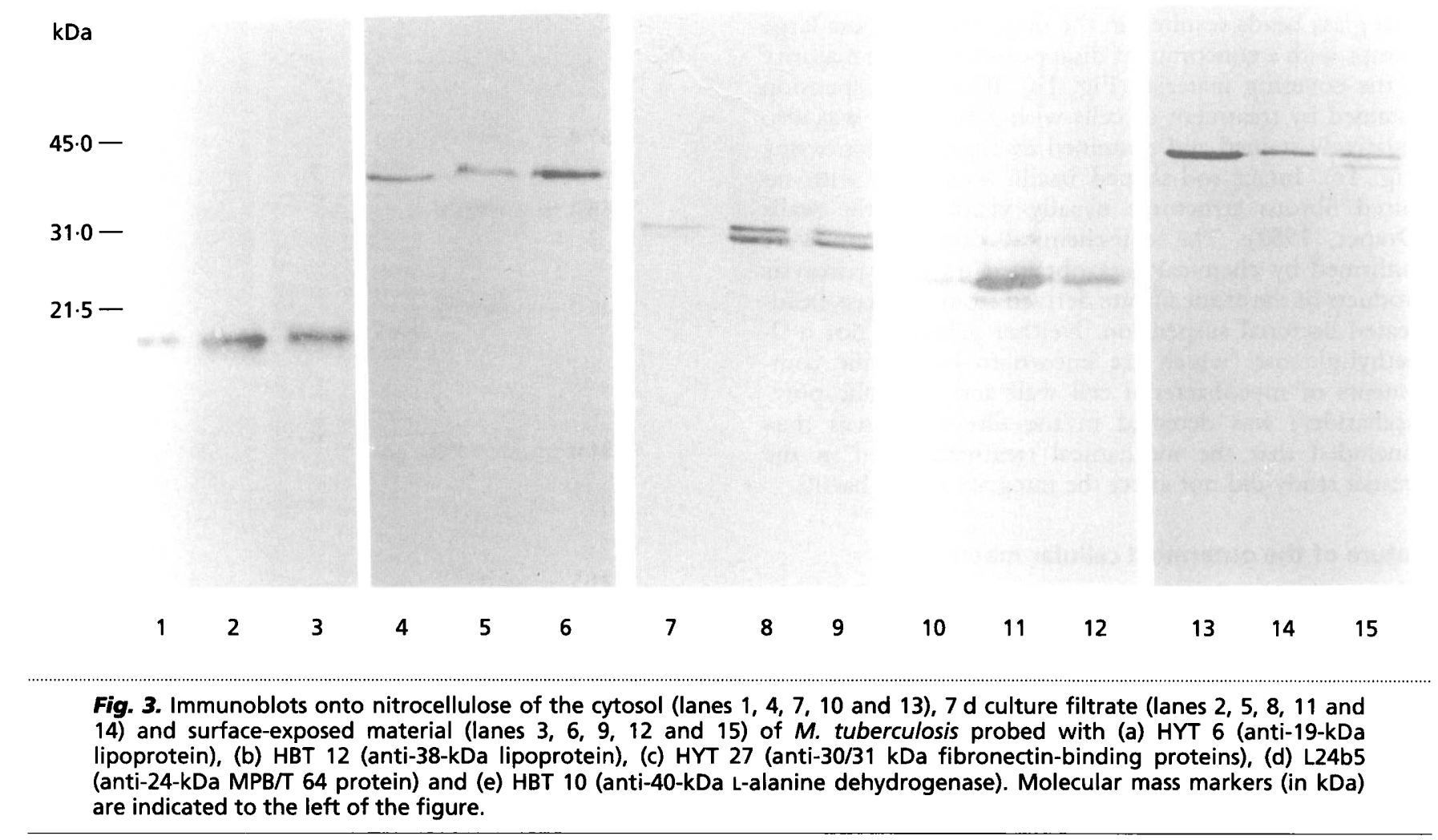

(c)

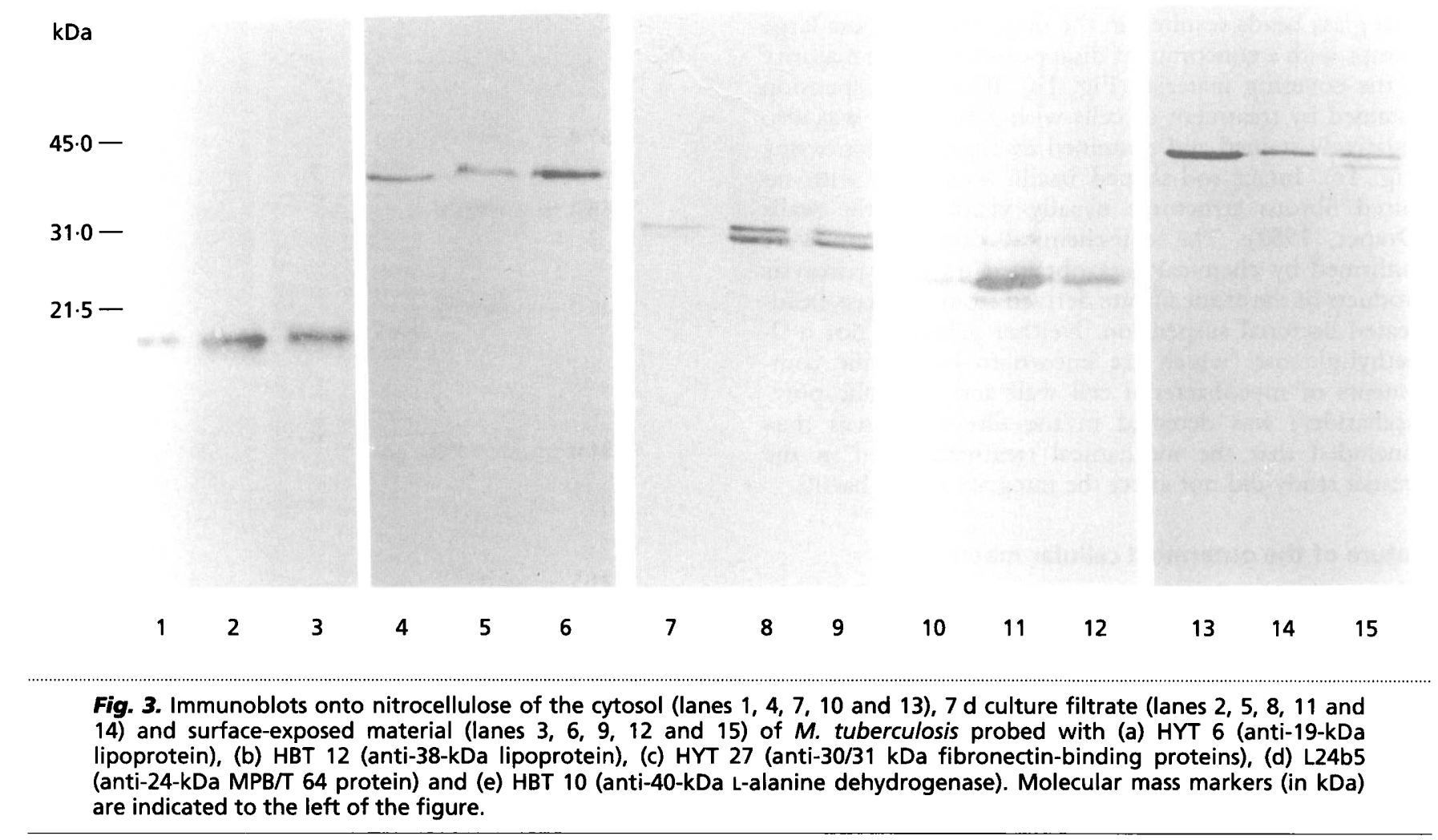

(d)

(e) reacted with the $24 \mathrm{kDa}$ (MPB/T 64) protein of the culture filtrate material while giving a faint reaction with the corresponding protein from the surface-exposed material (Fig. 3d), in accordance with the silver-stained gel (Fig. 2). Finally, the presence of the $40 \mathrm{kDa}$ L-alanine dehydrogenase in both the culture filtrate and the surfaceexposed material was demonstrated using HBT $10 \mathrm{mAb}$ (Fig. 3e). Although most of the enzyme is cytoplasmic, the occurrence of this protein in the early culture filtrate has been already demonstrated (Andersen et al., 1992). Interestingly, HBT $10 \mathrm{mAb}$ also recognized a $38 \mathrm{kDa}$ cellsurface-located protein which was not detectable in either the cytosol or the culture filtrate. This latter protein is probably different from the mycobacterial $38 \mathrm{kDa}$ lipoprotein recognized by the HBT $12 \mathrm{mAb}$ (see Fig. 3b). The relationship between the 40 and $38 \mathrm{kDa}$ proteins remains to be elucidated.

\section{Purification and characterization of the major polysaccharides}

Glc was the main sugar constituent $(70 \%)$ detected after acid hydrolysis of the polymers derived from the ethanol precipitation, which also contained $15 \%$ of Ara and $13 \%$ of Man. Small amounts ( $2 \%)$ of Xyl were also found in the hydrolysis products of the surface-exposed glycoconjugates. When a chloroform/methanol/water partition was applied to the material, the aqueous phase contained Ara, Man and Xyl, whereas Glc was the only constituent detected in the interphase. As $\mathrm{Xyl}$ was a minor component of the mixture, the subsequent experiments were focused on the isolation, purification and structural elucidation of the Glc-, Ara- and Man-containing compounds. Thus, the glucan was recovered as an opalescent 'glycogen-like' solution by extracting the interphase several times with water. The glucan was unretained on an anion-exchange column and was eluted at a position corresponding to an apparent molecular mass of $120 \mathrm{kDa}$ after gel-filtration chromatography over a Sephadex G-200 column (Lemassu \& Daffé, 1994). Analysis of the partially $O$ methylated alditol acetate derivatives revealed that $70 \%$ of the glucosyl residues were 4-linked-Glc $p$ (or 5-linkedGlc $f$ ); 4,6-Glc $p$ (or 5,6-Glc $f$ ) and terminal Glc $p(15 \%$ of each) were also detected. To determine the anomeric configuration and the ring form of the glucosyl residues, the glucan was subjected to ${ }^{1} \mathrm{H}$ - and ${ }^{13} \mathrm{C}$-NMR analyses. The ${ }^{1} \mathrm{H}$-NMR spectrum (Fig. 4a) showed two anomeric signals which were assigned to the resonances of $\mathrm{H}-1 \mathrm{~s}$ of the 4-linked- $\alpha$-D-Glc $p$ at 5.4 p.p.m. and to those of H-1s of the branched $\alpha$-Glc $p$ residues (Zang et al., 1991) at 5.0 p.p.m. The remaining upfield signals were attributed to the proton resonances of $\mathrm{H}-2-\mathrm{H}-6 \mathrm{~s}$. The ${ }^{13} \mathrm{C}-\mathrm{NMR}$ spectrum (Fig. 4b) showed the anomeric resonance signal at 101 p.p.m., which can only have resulted from the resonances of C-1s of $\alpha$-Glc $p$, those of $\beta$-Glc $p$ and of $\alpha$ and $\beta$-Glc $f$ being expected at lower field (104-110 p.p.m.; see Bradbury \& Jenkins, 1984). Because $O$-substitution of glycosyl residues at a given position is known to cause the corresponding carbon chemical shift to move upfield by 5-10 p.p.m. (Bradbury \& Jenkins, 1984) the signal at 
(a)

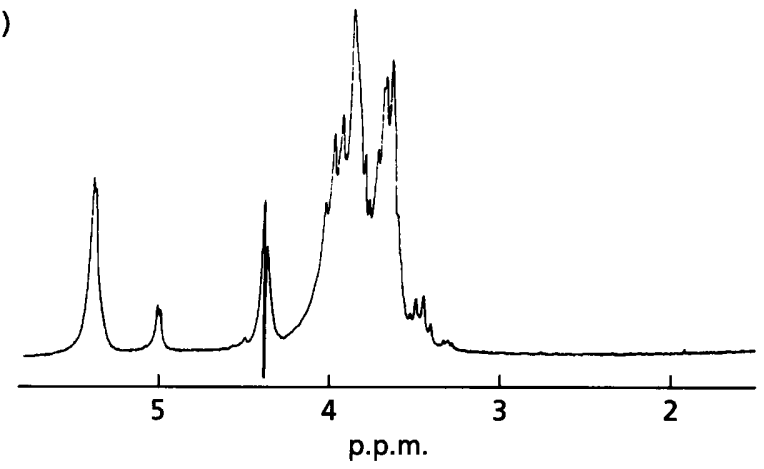

(b)

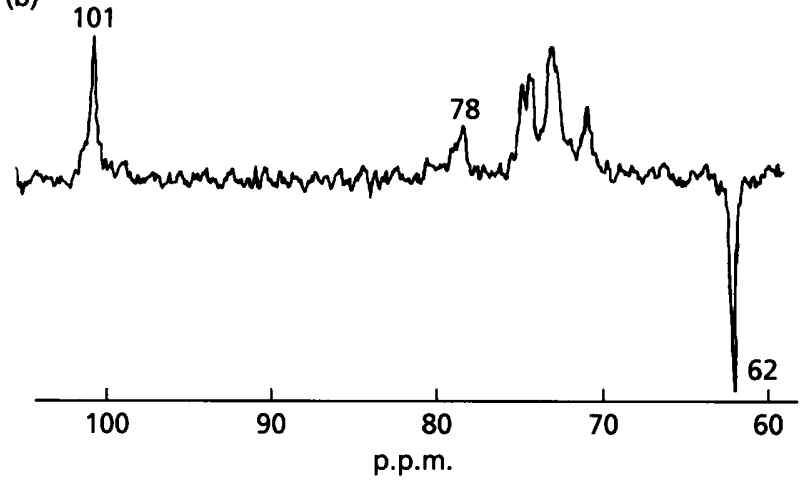

PAGE. Chromatography of these compounds over a BioGel P-10 column led to the isolation of an arabinomannan (molecular mass $13 \mathrm{kDa}$ ) and a mannan (molecular mass $4 \mathrm{kDa}$ ). The former polysaccharide was composed of terminal Araf $(0.6 \%)$, 2-linked-Araf $(6.2 \%)$, 5-linkedAraf $(35.5 \%), 3,5$-linked-Araf or 3,4-linked-Arap $(10.2 \%)$, terminal $\operatorname{Man} p(19.7 \%)$, 2-linked-Man $p$ $(14.5 \%)$, 6-linked-Man $p(4.7 \%)$ and 2,6-linked-Man $p$ $(9 \cdot 4 \%)$. The small amounts of terminal Araf compared with the percentage of branched Ara (3,5-Araf or 3,4Ara $p$ ) as well as the excess of terminal Man $p$ (as compared with the amount of 2,6-Man $p$ ) indicated the substitution of the non-reducing ends of the arabinan segment by either terminal Man $p$ or oligomannosyl residues (Chatterjee et al., 1992; Lemassu \& Daffé, 1994; Venisse et al., 1993). The ${ }^{13} \mathrm{C}-\mathrm{NMR}$ spectrum (data not shown) of the arabinomannan was superimposable on that isolated from the culture filtrate of $M$. tuberculosis (Lemassu \& Daffé, 1994), establishing that all the Ara residues occur in the furanose form. The absence of methylene and methyl proton and carbon signals in both ${ }^{1} \mathrm{H}$ - and ${ }^{13} \mathrm{C}$-NMR spectra of the arabinomannan (data not shown) demonstrated that the polysaccharide is devoid of acyl substituents. Acetolysis of the Man-containing polysaccharides demonstrated that both the mannan segment of the arabinomannan and the mannan consisted of a $\rightarrow 6)-\alpha-$ Man $p-(1 \rightarrow$ backbone substituted with a monomannosyl residue at some 2 positions as previously demonstrated for Man-containing exopolysaccharides of $M$. tuberculosis.

9. 4. $\mathrm{H}-\mathrm{NMR}$ (a) and ${ }^{13} \mathrm{C}-\mathrm{NMR}$ (b) spectra of the surfaceexposed glucan of $M$. tuberculosis. The ${ }^{13} \mathrm{C}$-NMR spectrum was obtained using a Bruker J-modulated sequence. Thus, the resonance signals of $\mathrm{CH}$ and $\mathrm{CH}_{3}$ were phase positive whereas those of $\mathrm{CH}_{2}$ were phase negative.

78 p.p.m was assigned to the resonance of C-4s of 4linked- $\alpha$-Glc $p$ (Bradbury \& Jenkins, 1984; Zang et al., 1991). The unsubstituted C-2s, C-3s and C-5s had their resonances between 70 and 73 p.p.m. while the resonance of unsubstituted C-6s was seen at 62 p.p.m. (Bradbury \& Jenkins, 1984; Zang et al., 1991). No signal attributable to the presence of a lipid substituent (methyl and methylene proton resonances) was observed in the NMR spectra. Thus, the poor solubility of the glucan in water is due to its intrinsic structural features, rather than to a modest degree of lipoylation.

Acetolysis applied to the glucan resulted in the identification of mono- and diglucosides by both TLC and MS. In the mass spectrum (Fig. 5), the pseudomolecular ion $(M+\mathrm{Na})^{+}$peaks were seen at $m / z 413$ and 701 . They correspond to peracetylated mono- and diglucosides. Fragments were observed at $m / z 331$ and 619 and corresponded to the glucosyl and diglucosyl oxonium ions, respectively. These results support a structure identical to that of the exocellular glucan of $M$. tuberculosis (Lemassu \& Daffé, 1994), based on a linear 4-linked- $\alpha$-DGlc $p$ substituted by a mono- or a diglucosyl residue at some 6 positions.

The Ara/Man-containing substances were mainly ( $90 \%)$ neutral polysaccharides as they were unretained on the anion-exchange column and did not migrate on SDS-

\section{Cyto- and immunocytochemistry}

To confirm the location of these polysaccharides at the outermost compartment of the bacilli, cytochemical and immunocytochemical studies were done on control and treated cells using gold-labelled ConA (which binds Glcand Man-containing glycoconjugates) and L9 (Gaylord $e t$ al., 1987), a specific mAb directed against the arabinomannan segments of LAM. The reactivity of L9 was tested against AG and PIMs, using a Man-capped LAM of M. tuberculosis $\mathrm{H}_{37} \mathrm{Rv}$ (Venisse et al., 1993) as a control. As shown in Fig. 6, AG, but not PIM, reacted with L9 demonstrating that it recognized common epitope(s) of the arabinan segments of the polysaccharides. This result confirmed a previous observation stating that some $\mathrm{mAbs}$ directed against LAM also reacted with AG (Daffé et al., 1990).

As shown in Fig. 7, gold-labelled ConA strongly reacted with the surface of bacilli (Fig. 7b). When the binding sites of ConA were saturated with methyl- $\alpha$-mannoside prior to the cytochemical reaction of the lectin with cells, no labelling was observed (Fig. 7a), establishing the specificity of the reaction. Gold-labelled L9 also reacted with the cell surface (Fig. 8a), suggesting that the $\mathrm{mAb}$ probably recognizes an internal arabinan motif, as the major surface-exposed Ara-containing glycan is extensively capped by mannosyl residues (see earlier). Mechanically treated cells also reacted with both gold-labelled ConA and L9 (data not shown), demonstrating that the treatment of the bacilli with glass beads did not extract all of the polysaccharides from the cell surface. These data 


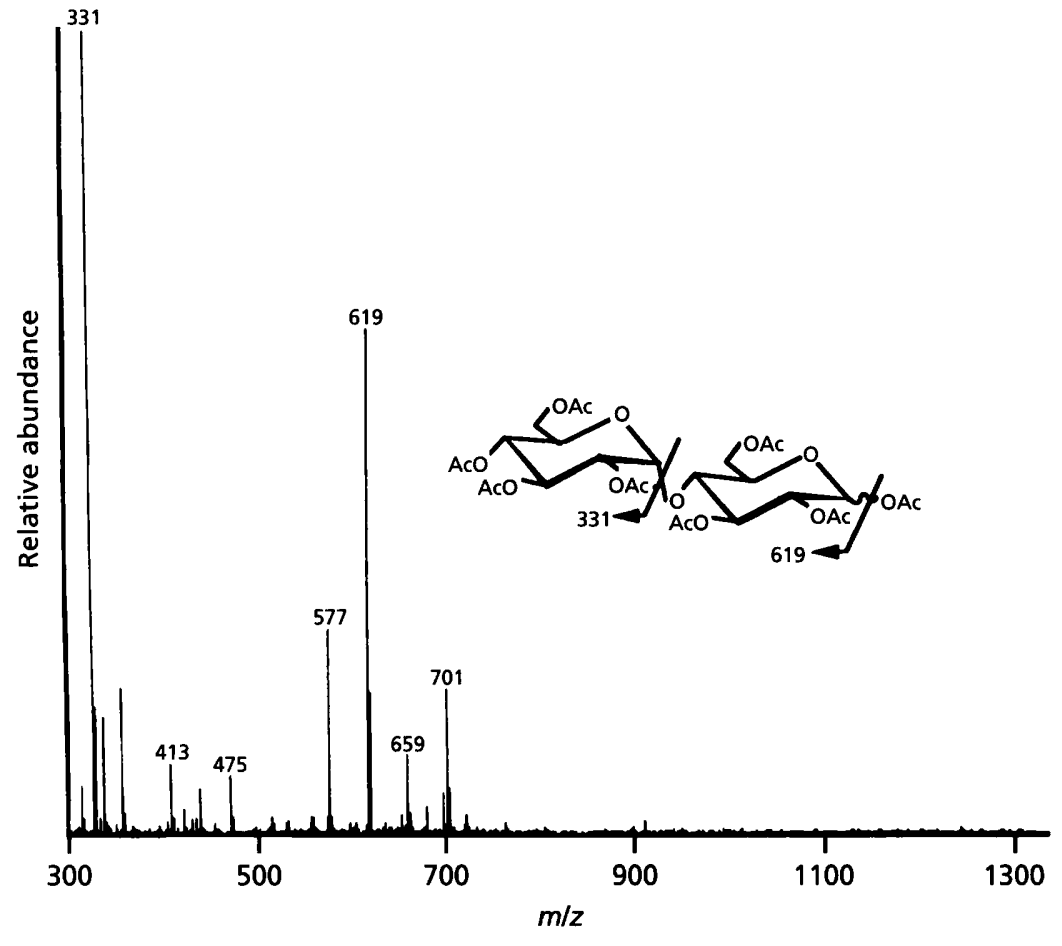

Fig. 5. FAB-MS spectrum of the acetolysis products of the surface-exposed glucan of M. tuberculosis.

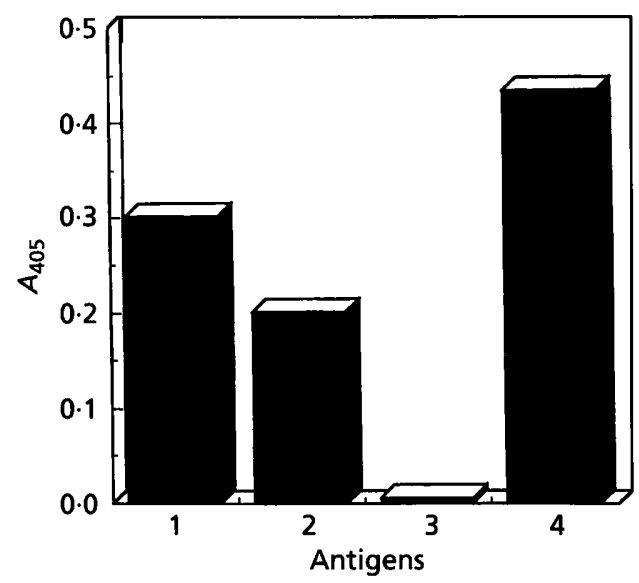

Fig. 6. Seroreactivity of various mycobacterial antigens with the L9 mAb. 1, Sonicated cells; 2, AG; 3, PIMs; 4, LAM.

suggested that either the mechanical treatment was incomplete or that the reacting polysaccharides were also present in the inner compartment of the capsule. To test the latter hypothesis, gold-labelled L9 was used on cryofixed sections of treated cells. As shown in Fig. 8b, significant labelling was observed not only on the cell surface, but also in the inner compartment of the capsule, demonstrating the presence of arabinan-containing polysaccharides in the cell envelope. These include the arabinomannan characterized herein and the covalently attached cell wall AG. As expected, heavy labelling in the bacterial cytoplasm was also observed, indicating the occurrence of active biosynthesis of these polysaccharides.

\section{DISCUSSION}

In order to gain insight into the pathogenesis of tuberculosis, we investigated the chemical nature of the outermost constituents of the tubercle bacillus. These compounds were isolated by a gentle shaking of cells with glass beads, a commonly used method for dispersing mycobacterial clumps (Buttiaux et al., 1966; Kreis, 1966). This mechanical treatment was shown by both transmission and scanning electron microscopy and by chemical analyses to preserve the integrity of the bacilli. We showed that treatment of cells by glass beads extracted a material covering the bacilli and probably responsible for their aggregation. Careful chemical analyses demonstrated the absence of covalently linked cell wall and cytosolic components in the extracted material. This material consists mainly (roughly $97 \%$ ) of proteins and polysaccharides. A $120 \mathrm{kDa}$ glycogen-type glucan, a $13 \mathrm{kDa}$ arabinomannan and a $4 \mathrm{kDa}$ mannan were the major surface-exposed capsular polysaccharides identified. Tiny amounts of a xylan, not previously described in the literature, were also present. The structural features of the major polysaccharides were found to be identical to those isolated from the culture filtrate (Lemassu \& Daffé, 1994). That the polysaccharides characterized herein are not generated due to physical shearing of originally covalently linked polymers merits consideration. Although arabinomannan and mannan are structurally and presumably biosynthetically related to LAM and lipomannan (LM), the former polysaccharides were found as non-lipidated exocellular constituents of the tubercle bacillus (Lemassu \& Daffé, 1994). Similarly, while the glucan exhibited an apparent molecular mass of $120 \mathrm{kDa}$, cytosolic mycobacterial glycogen has been found with a mean 
(a)
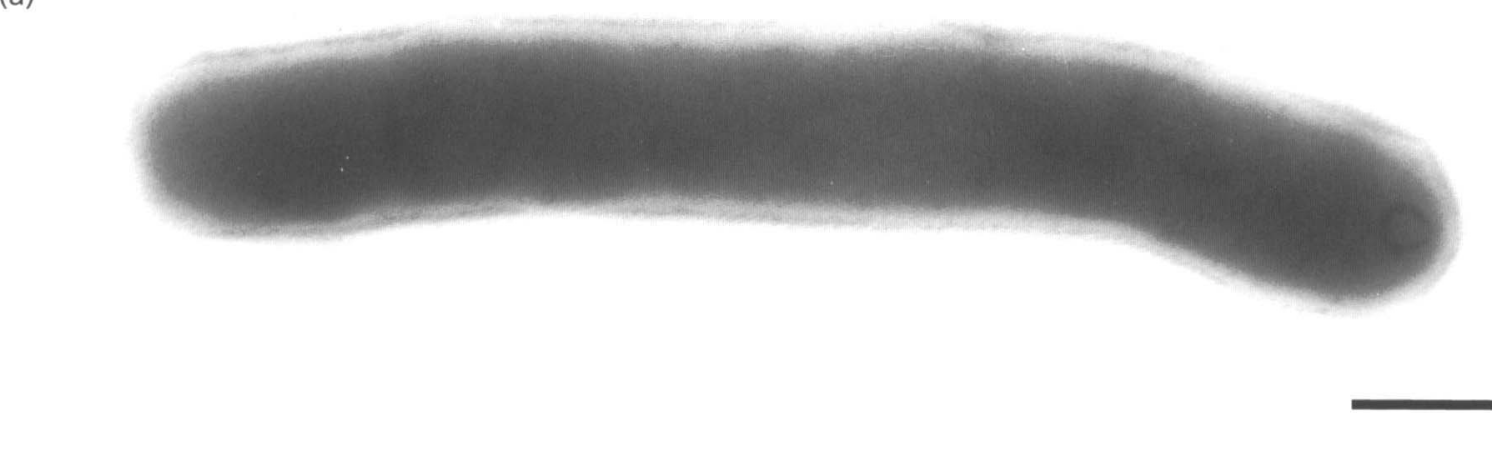

(b)

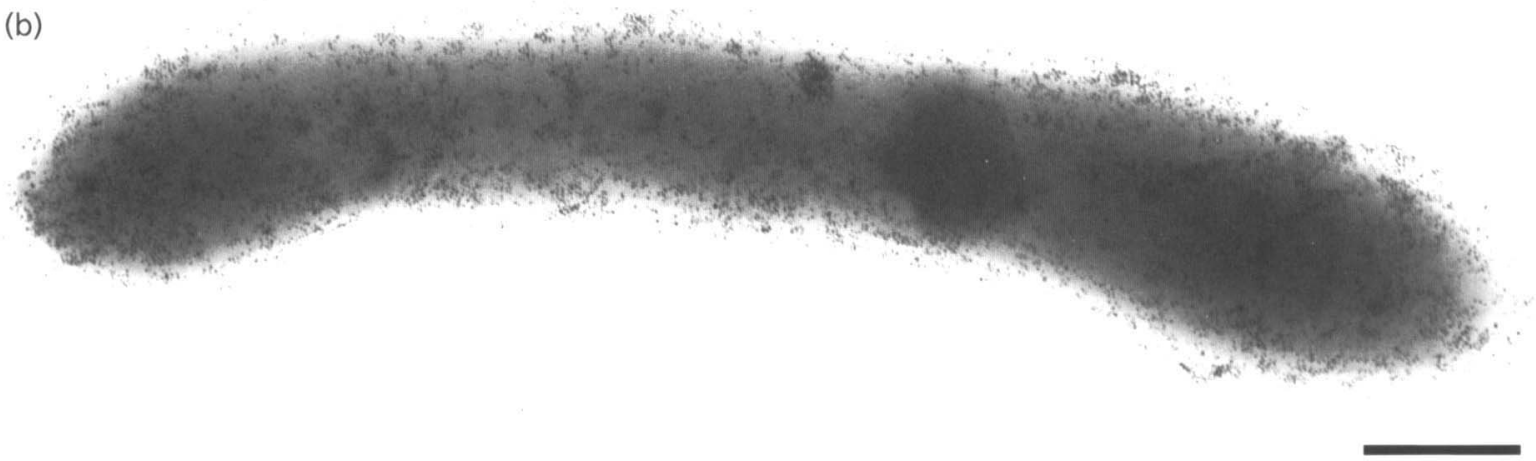

Fig. 7. Cytochemistry of $M$. tuberculosis. Control cells (a) incubated with a gold $(5 \mathrm{~nm})$-labelled ConA solution pretreated with methyl- $\alpha$-Manp were devoid of labelling; in contrast, untreated gold $(5 \mathrm{~nm})$-labelled ConA strongly reacted with the surface of the cells (b). Bars, $250 \mathrm{~nm}$.

molecular mass 1000 -fold greater than that determined for the glucan (Antoine \& Tepper, 1969). Furthermore, the length of the branched segments differs in the two polysaccharides: one glucosyl residue substitutes some six positions of the glucan core whereas seven to nine glucosyl units $(\alpha-1 \rightarrow 4$ linked) are present in the branched segments of the glycogen isolated from $M$. tuberculosis (Antoine \& Tepper, 1969). In addition, the expected heterogeneity in the size distribution of the glucan if this polysaccharide was derived from the shearing of glycogen was not observed. Convincing evidence of the fact that the polysaccharides characterized in the present study did not result from shearing of larger molecules, but instead occur in their native form as neutral and lipid-free polysaccharides, lies in the analysis of the compounds extracted by treatment of grown cells with detergents (instead of beads). When cells were treated overnight with either $1 \%$ Tween 80 or Triton WR 1339, the treatment resulted in the isolation of neutral and non-lipidated polysaccharides exhibiting the same structural features as those of the compounds obtained from the surface of bacilli by beads (our unpublished results). The occurrence of large amounts of polysaccharides in the outermost compartment of the bacterial capsule is in agreement with previous findings demonstrating that purified cell walls of tubercle bacilli still contain highly branched glycogentype $\alpha$-glucan (Amar-Nacasch \& Vilkas, 1970; Misaki \& Yukawa, 1966) structurally related to the major capsular polysaccharide characterized in the present study. The surface location of these polysaccharides was further substantiated by the cytochemical and immunocytochemical data presented herein, in accordance with published data showing that mycobacteria are endowed with concanavalin-reacting compounds (Picard et al., 1984).

The presence of the arabinomannan at the cell surface may explain some immunological reactions in response to the tubercle bacillus or its products. These include the suppression of macrophage-dependent, antigen-induced activation of human lymphocytes (Ellner \& Daniel, 1979) and the inhibition of the processing of the antigen by antigen-presenting T-cells (Moreno et al., 1988). Mention should be made of the potential role of the surfaceexposed arabinomannan in the host-tubercle bacillus interactions. It has been shown that macrophage phagocytosis of virulent tubercle bacilli is mediated by Man receptors (Schlesinger, 1993). Although coating polystyrene microspheres with Man-capped LAM, but not with LM, has been shown to enhance adherence of microspheres to human-monocyte-derived macrophages (Schlesinger et al., 1994), the bacterial surface-exposed Man-containing glycans have not yet been identified. By showing in the present study that Man-capped arabinomannan is the major surface-exposed Man-containing polysaccharide of a virulent tubercle bacillus, the 
(a)

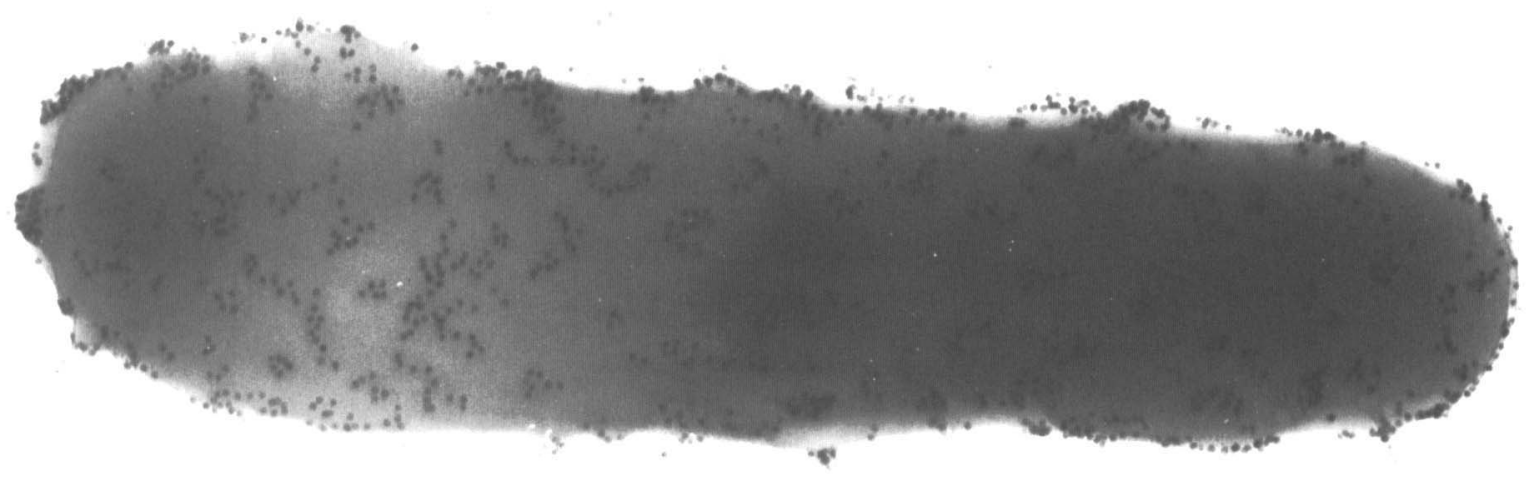

(b)

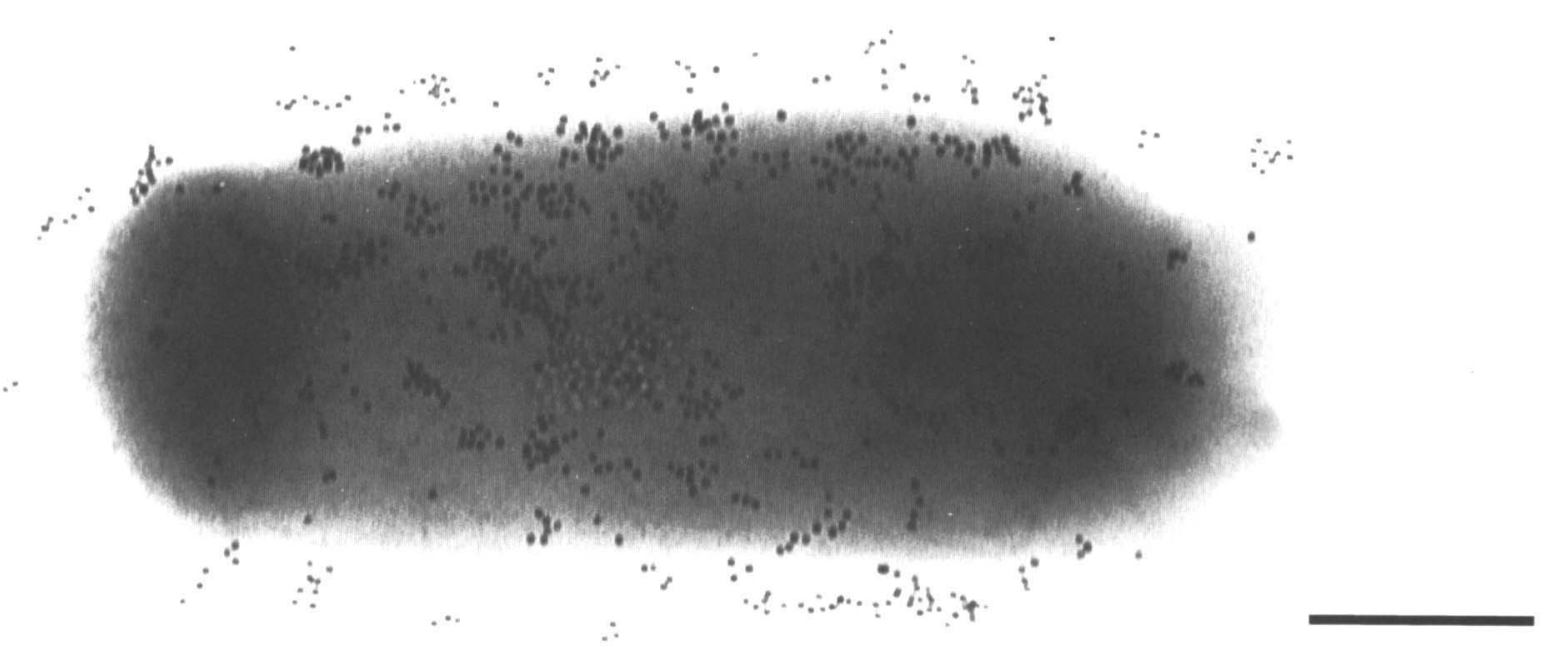

Fig. 8. Immunogold-labelled cells (a) and an immunogold-labelled cryofixed thin section of glass-bead-treated cells (b) using the anti-arabinan $\mathrm{mAb} \mathrm{L} 9$ as the primary antibody, followed by incubation with colloidal-gold (10 nm)-conjugated anti-mouse IgG antibodies. Bars, $250 \mathrm{~nm}$.

mannosyl residues of this glycan are the obvious candidates for being the counterparts of the Man receptors.

Several surface-exposed capsular proteins were also detected by SDS-PAGE of the polymers derived from the mechanical treatment of the cells. The general profile of these proteins is similar to that of the culture filtrate proteins. Some of the former material was identified by Western blot, using available mAbs directed against selected proteins of the tubercle bacillus. By this method, the 19 and $38 \mathrm{kDa}$ lipoproteins, as well as the fibronectinbinding proteins $(30 / 31 \mathrm{kDa})$, were located at the cell surface, in agreement with published data (Abou-Zeid et al., 1988; Espitia et al., 1992; Rambukkana et al., 1991). It has to be noted that only one fibronectin-binding protein band was detected in the cytosol fraction. Its molecular mass $(31 \mathrm{kDa})$ and immunoreaction with HYT $27 \mathrm{mAb}$ suggest that it corresponds to antigen $85 \mathrm{C}$ (MPT 45; see
Wiker \& Harboe, 1992). The occurrence at the cell surface of the $40 \mathrm{kDa}$ L-alanine dehydrogenase (Andersen et al., 1992) was revealed by immunoblot using HBT 10 $\mathrm{mAb}$. However, this latter enzyme was mainly found in the cytosolic fraction. Mention should also be made of the detection of a previously undescribed $38 \mathrm{kDa}$ protein reacting with $\mathrm{HBT} 10 \mathrm{mAb}$ at the cell surface where this protein seems to be confined. Further studies are needed in order to define the relationship between this protein and the L-alanine dehydrogenase. It has to be noted, however, that, in contrast to the other proteins mentioned above, the MBP/T 64 protein $(24 \mathrm{kDa})$ was found almost exclusively in the culture filtrate, as seen on SDS-PAGE. These data suggest that among the proteins of the culture filtrate, some are truly secreted in the environment of the cells.

The material extracted by the mechanical treatment 
contained only small amounts of lipids, suggesting that most of the free (non-covalently linked) lipids are not surface-exposed in the tubercle bacillus. This finding is surprising in that the characteristic mould-like growth pattern of tubercle bacilli in stationary liquid culture is currently attributed to their high lipid content (Goren \& Brennan, 1979). Therefore, the molecular basis of tubercle bacilli aggregation has to be reinvestigated.

The occurrence of the same polysaccharides and most of the proteins previously described in the culture filtrate at the cell surface raises the question of the origin of this material. It is important to recall in this connection that the outermost constituents of the bacilli have the tendency to disperse into the surrounding liquid medium in which the organism is growing, especially when shaking is used during the growth, rather than accumulate around the bacteria. In support of that fact is our unpublished observation that traces of surface-exposed xylan and lipids may be found in the culture filtrate of tubercle bacilli. Thus, it is tempting to postulate that the exocellular polysaccharides and proteins derive from the capsule of the tubercle bacillus. In an in vivo environment such as macrophage, the large amounts of the in vitro exocellular polymers (up to $20 \%$ of the dried bacterial mass; Lemassu \& Daffé, 1994) would explain the volume of the capsule surrounding the bacilli and called in that context the 'electron transparent zone' (Armstrong \& D'Arcy Hart, 1971, 1975; Merckx et al., 1964). Examination of the capsule constituents of $M$. tuberculosis grown inside infected cells is needed in order to validate this hypothesis. Nevertheless, the occurrence of large amounts of glucan, arabinomannan and mannan at the surface of $\mathrm{H}_{37} \mathrm{Rv}$ constantly maintained through passages on mice (our unpublished results) suggests that the elaboration of these polysaccharides occurs in infected cells.

\section{ACKNOWLEDGEMENTS}

We are grateful to Dr P. Draper (NIMR, London), Professor G. Marchal (Institut Pasteur, Paris) and Professor G. Lanéelle (LPTF du CNRS, Toulouse) for stimulating discussions. We also thank Drs M.-A. Lanéelle, J.-J. Fournié, J. Roussel, F. Talmont and Miss V. Ozanne (LPTF du CNRS, Toulouse) for their help. This work was supported in part by contract no. 920609 from the Institut National de la Santé et de la Recherche Médicale (INSERM, France).

\section{REFERENCES}

Abou-Zeid, C., Ratliff, T. L., Wiker, H. G., Harboe, M., Bennedsen, J. \& Rook, G. A. W. (1988). Characterization of fibronectin-binding antigens released by Mycobacterium tuberculosis and Mycobacterium bovis BCG. Infect Immun 56, 3046-3051.

Amar-Nacasch, C. \& Vilkas, E. (1970). Étude des parois de Mycobacterium tuberculosis. II. Mise en évidence d'un mycolate d'arabinobiose et d'un glucane dans les parois de $M$. tuberculosis $\mathrm{H}_{37} \mathrm{Ra}$. Bull Soc Chim Biol 52, 145-151.

Andersen, A. B., Yuan, Z. L., Haslov, K., Vergmann, B. \& Bennedsen, J. (1986). Interspecies reactivity of five monoclonal antibodies to Mycobacterium tuberculosis as examined by immunoblotting and enzyme-linked immunosorbent assay. Infect Immun 23, 446-451.
Andersen, A. B., Ljungqvist, L., Haslov, K. \& Bentzon, M. W. (1991). MPB 64 possesses 'tuberculosis-complex'-specific B- and T-cell epitopes. Scand J Immunol 34, 365-372.

Andersen, A. B., Andersen, P. \& Ljungqvist, L. (1992). Structure and function of a 40,000-molecular-weight protein antigen of Mycobacterium tuberculosis. Infect Immun 60, 2317-2323.

Andersen, P., Askgaard, D., Ljungqvist, L., Bennedsen, J. \& Heron, I. (1991). Proteins released from Mycobacterium tuberculosis during growth. Infect Immun 59, 1905-1910.

Antoine, A. D. \& Tepper, B. S. (1969). Characterization of glycogens from mycobacteria. Arch Biochem Biopbys 134, 207-213.

Armstrong, J. A. \& D'Arcy Hart, P. D. (1971). Response of cultured macrophages to Mycobacterium tuberculosis with observation on fusion of lysosomes with phagosomes $J$ Exp Med 134, 713-740.

Armstrong, J. A. \& D'Arcy Hart, P. D. (1975). Phagosome-lysosome interactions in cultured macrophages infected with virulent tubercle bacilli. Reversal of the usual non-fusion pattern and observation on bacterial survival. $J$ Exp Med 142, 1-16.

Bloom, B. R. \& Murray, J. L. (1992). Turberculosis : commentary on a reemergent killer. Science 257, 1055-1064.

Boddingius, J. \& Dijkman, H. P. (1989). Immunogold labelling method for Mycobacterium leprae-specific phenolic glycolipid in glutaraldehyde-osmium-fixed and araldite-embedded leprosy lesion. J Histochem Cytochem 37, 455-462.

Bradbury, J. H. \& Jenkins, G. A. (1984). Determination of the structures of trisaccharides by ${ }^{13} \mathrm{C}-\mathrm{NMR}$ spectroscopy. Carbobydr Res 126, 125-156.

Buttiaux, R., Beerens, H. \& Tacquet, A. (1966). Mycobactéries. In Manuel de Techniques Bactériologiques, 2nd edn, pp. 477-547. Edited by R. Buttiaux, H. Beerens \& A. Tacquet. Paris: Flammarion.

Chatterjee, D., Lowell, K., Rivoire, B., McNeil, M. R. \& Brennan, P. J. (1992). Lipoarabinomannan of Mycobacterium tuberculosis: capping with mannosyl residues in some strains. J Biol Chem 267, 6234-6239.

Ciucanu, I. \& Kerek, F. (1984). A simple and rapid method for permethylation of carbohydrates. Carbobydr Res 131, 209-217.

Daffé, M., Lacave, C., Lanéelle, M.-A. \& Lanéelle, G. (1987). Structure of the major triglycosyl phenol-phthiocerol of Mycobacterium tuberculosis (strain Canetti). Eur J Biochem 167, 155-160.

Daffé, M., Brennan, P. J. \& McNeil, M. (1990). Predominant structural features of the cell wall arabinogalactan of Mycobacterium tuberculosis as revealed through characterization of oligoglycosyl alditol fragments by gas chromatography/mass spectrometry and by ${ }^{1} \mathrm{H}$ - and ${ }^{13} \mathrm{C}-\mathrm{NMR}$ analyses. $J$ Biol Chem 265, 6734-6743.

Daffé, M., Cho, S.-N., Chatterjee, D. \& Brennan, P. J. (1991a). Chemical synthesis and seroreactivity of a neoantigen containing the oligosaccharide hapten of the Mycobacterium tuberculosis-specific phenolic glycolipid. J Infect Dis 163, 161-168.

Daffé, M., McNeil, M. \& Brennan, P. J. (1991b). Novel type-specific lipooligosaccharides from Mycobacterium tuberculosis. Biochemistry $\mathbf{3 0}$, 378-388.

Dische, Z. (1962). Color reaction of hexoses. Methods Carbobydr Chem 1, 488-494.

Draper, P. (1982). The anatomy of mycobacteria. In The Biology of the Mycobacteria, vol. 1, pp. 9-52. Edited by C. C. Ratledge \& J. L. Stanford. London: Academic Press.

Draper, P. \& Rees, R. J. W. (1970). Electron transparent zone of mycobacteria may be a defence mechanism. Nature 228, 860-861.

Draper, P. \& Rees, R. J. W. (1973). The nature of the electrontransparent zone that surrounds Mycobacterium lepraemurium inside host cells. J Gen Microbiol 77, 79-87. 
Ellner, J. J. \& Daniel, T. M. (1979). Immunosuppression by mycobacterial arabinomannan. Clin Exp Immunol 35, 250-257.

Espitia, C., Elinos, M., Hernandez-Pando, R. \& Mancilla, R. A. (1992). Phosphate starvation enhances expression of the immunodominant 38-kilodalton protein antigen of Mycobacterium tuberculosis: demonstration by immunogold electron microscopy. Infect Immun 60, 2998-3001.

Fournié, J. J., Mullins, R. J. \& Basten, A. (1991). Isolation and structural characteristics of a monoclonal antibody-defined crossreactive phospholipid antigen from Mycobacterium tuberculosis and Mycobacterium leprae. J Biol Cbem 266, 1211-1219.

Gaylord, H., Brennan, P. J., Young, D. B. \& Buchanan, T. M. (1987). Most Mycobacterium leprae carbohydrate-reactive monoclonal antibodies are directed to lipoarabinomannan. Infect Immun 55, 2860-2863.

Gerwig, G. J., Kamerling, J. B. \& Vliegenthart, J. F. G. (1978). Determination of the $\mathrm{D}$ and $\mathrm{L}$ configuration of neutral monosaccharides by high-resolution capillary GLC. Carbobydr Res 62, 349-357.

Goren, M. B. \& Brennan, P. J. (1979). Mycobacterial lipids. In Tuberculosis, pp. 69-193. Edited by G. P. Youmans. Philadelphia: W. B. Saunders.

Hanks, J. H. (1961). Significance of capsular components of Mycobacterium leprae and other mycobacteria. Int J Lepr 29, 74-83.

Hunter, S. W. \& Brennan, P. J. (1983). Further specific phenolic glycolipid antigens and a related diacyl phthiocerol from Mycobacterium leprae. J Biol Chem 258, 7556-7562.

Kochi, A. (1991). The global tuberculosis situation and the new control strategy of the World Health Organization. Tubercle 72, $1-6$.

Koul, A. K. \& Gastambide-Odier, M. (1977). Microanalyse rapide de dimycocérosate de phtiocérol, de mycosides et de glycérides dans les extraits à l'éther de pétrole de Mycobacterium kansasii et du BCG, souche Pasteur. Biochimie 59, 535-538.

Kreis, B. (1966). La mesure de la résistance. In Résistance et Survivance du Bacille Tuberculeux aux Médicaments Antibacillaires, pp. 45-73. Edited by B. Kreis. Paris: Masson et $\mathrm{C}^{\text {ie }}$.

Lemassu, A. \& Daffe, M. (1994). Structural features of the exocellular polysaccharides of Mycobacterium tuberculosis. Biochem $J$ 297, 351-357.

Ljungqvist, L., Worsaae, A. \& Heron, I. (1988). Antibody responses against Mycobacterium tuberculosis in 11 strains of inbred mice: novel monoclonal antibody specificities generated by fusions, using spleens from BALB. B10 and CBA/J mice. Infect Immun 56, 1994-1998.
Merckx, J. J., Brown, A. L. \& Karlson, A. G. (1964). An electronmicroscopic study of experimental infection with acid-fast bacilli. Am Rev Respir Dis 89, 485-496.

Misaki, A. \& Yukawa, S. (1966). Studies on cell walls of mycobacteria. II. Constitution of polysaccharides from BCG cell walls. J Biochem 59, 511-520.

Moreno, C., Mehlert, A. \& Lamb, J. (1988). The inhibitory effects of mycobacterial lipoarabinomannan and polysaccharides upon polyclonal and monoclonal human $\mathrm{T}$ cell proliferation. Clin Exp Immunol 74, 206-210.

Patel, A. M. \& Abraham, E. W. (1989). Pulmonary tuberculosis. In The Biology of the Mycobacteria, vol. 3, pp. 179-244. Edited by C. Ratledge, J. Stanford \& J. M. Grange. London: Academic Press.

Picard, B., Frehel, C. \& Rastogi, N. (1984). Cytochemical characterization of mycobacterial outer surfaces. Acta Lepr 95, 227-235.

Rambukkana, A., Das, P. K. A., Chand, A., Baas, J. G., Groothuis, D. G. \& Kolk, A. H. J. (1991). Subcellular distribution of monoclonal antibody defined epitopes on immunodominant Mycobacterium tuberculosis proteins in the $30-\mathrm{kDa}$ region: identification and localization of $29 / 33-\mathrm{kDa}$ doublet proteins on mycobacterial cell wall. Scand J Immunol 33, 763-775.

Sauton, B. (1912). Sur la nutrition minérale du bacille tuberculeux. C R Acad Sci Ser III Sci Vie 155, 860-863.

Schlesinger, L. S. (1993). Macrophage phagocytosis of virulent but not attenuated strains of Mycobacterium tuberculosis is mediated by mannose receptors in addition to complement receptors. J Immunol 150, 2920-2930.

Schlesinger, L. S., Hull, S. R. \& Kaufman, T. M. (1994). Binding of the terminal mannosyl units of lipoarabinomannan from a virulent strain of Mycobacterium tuberculosis to human macrophages. JImmunol 152, 4070-4079.

Stewart, T. S. \& Ballou, C. E. (1968). A comparison of yeast mannans and phosphomannans by acetolysis. Biochemistry $\mathbf{7}$, 1855-1863.

Venisse, A., Berjeaud, J. M., Chaurand, P., Gilleron, M. \& Puzo, G. (1993). Structural features of lipoarabinomannan from Mycobacterium bovis BCG. $J$ Biol Chem 268, 12401-12411.

Wiker, H. G. \& Harboe, M. (1992). The antigen 85 complex : a major secretion product of Mycobacterium tuberculosis. Microbiol Rev 56, 648-661.

Zang, L.-H., Howseman, A. M. \& Shulman, R. G. (1991). Assignment of ${ }^{1} \mathrm{H}$ chemical shifts of glycogen. Carbobydr Res 220, 1-9.

Received 1 November 1994; revised 3 January 1995; accepted 9 March 1995. 